\title{
Brussels inquiry criticizes BSE secrecy
}

Paris. Serious flaws in the management of bovine spongiform encephalopathy (BSE) by the European Union (EU) are emerging from an inquiry into the 'mad cow' crisis by the European Parliament. Testimony given to the inquiry points to the failure of the European Commission (EC) to monitor adequately the enforcement of BSE control measures by member states, and to excessive secrecy in the way the commission makes decisions.

The inquiry is likely to recommend that the management of animal and public health within the EU's institutions should be brought under consumer protection rather than agriculture as at present, according to one source close to the inquiry committee. The source says the current set-up has been a recipe for conflicts of interest, where agricultural priorities have tended to prevail over those of public health.

The committee of inquiry has focused in particular on allegations that the commission suppressed information on BSE, and on evidence that UK exports of meat and bone meal increased substantially after the government banned its use in ruminant feed within the United Kingdom in 1988 (see Nature 381, 544; 1996).

The commission has come under fire following revelations in a memo written by one official, Gérard Castille, which records how an unnamed commission official had recommended "minimizing the BSE affair by practising disinformation" and "officially asking the United Kingdom to stop publishing its research".

The commission has argued that the memo reflected the view of an isolated civil servant, and not commission policy. One source close to the inquiry says it has found no firm evidence of a deliberate cover-up.

The commission has also provided a strong defence against allegations that it failed to prevent the threat posed by contaminated meat and bone meal. In July 1989, it proposed a ban on the export of meat and bone meal from the United Kingdom. But Britain refused, according to Lars Hoelgaard, head of the EC agriculture directorate's department of quality and health. He says that the commission then tried to introduce a European Community-wide ban on feeding ruminant protein to ruminants.

But this proposal was rejected by member states and by the commission's scientific veterinary committee. So the commission could only advise member states to introduce individual feed bans. Only France, Ireland, Denmark and the Netherlands did so. Other member states, including Germany, reacted only after the commission used its powers under the European single market to introduce a community-wide ban in 1994.

Hoelgaard says: "Here was a case where we didn't have the scientific evidence or the powers to introduce a ban [in 1989], but where we saw feed was the cause and asked member states to impose their own bans."

The council of agriculture ministers of the member states comes under fire in the inquiry's draft conclusions for having pursued "minimalist policies" on BSE. Recent evidence of this comes from a meeting of ministers last week that rejected a proposal from the commission for stricter precautions against BSE in the light of a study showing that the new variant of Creutzfeldt-Jakob disease (CJD) was similar to BSE (see Nature 383, 685-690; 1996). The commission's proposed measures had been endorsed by its scientific veterinary committee.

Franz Fischler, EU agriculture commissioner, described the measures - which included a ban on sheep offals - as "absolutely necessary", arguing that "the precautionary principle must be an absolute priority". But several member states argued that the measures would penalize their economies even though they did not have BSE epidemics. The commission will resubmit its proposals to agriculture ministers at their next meeting later this month.

These events are a reminder that it is the council of ministers that ultimately pulls the strings of power in the EU. Ken Collins,

\section{IMAGE UNAVAILABLE FOR COPYRIGHT REASONS}

\section{Next in line? EC officials claim that a ban on sheep offals is 'absolutely necessary'.}

chairman of the European Parliament's committee on environment, public health and consumer protection, says: "The more you look at the realpolitik of how the commission relates to the member states, you realize it has had to watch its step all the time."

Collins, who has often been an outspoken critic of the commission, says: "With BSE, the commission has been in the position of 'damned if it does and damned if it doesn't'." Had the commission taken tougher action against Britain earlier, the UK government would have gone to the media saying "look at these unelected bureaucrats" jeopardizing our beef industry, says Collins. He adds that if the commission had not adhered to scientific advice it could have been taken to the European Court of Justice or the World Trade Organization for blocking free trade. "In retrospect, the commission was too reluctant to take on the member states," he says.

One example of this is the failure of the commission to sufficiently monitor the implementation of BSE control measures in Britain. It began monitoring this in the first half of 1990 as part of routine inspections to ensure that abattoirs producing meat for export met EU standards. But all BSE inspections then ceased until 1994.

Guy Legras, director-general of the EC's agricultural directorate, DG6, has attributed this failure to understaffing of the commissions's veterinary inspectorate, which had only a dozen individuals, compared with the estimated 200 required. "We did a poor job on inspections," admits Hoelgaard, who describes the sudden cessation of inspections as a "mystery".

The inspectors thought that they only had to inspect BSE control measures in Britain as a one-off exercise in the first half of 1990 , says Hoelgaard, whereas he had understood it as a "standing instruction".

But a more sinister explanation emerges from reports commissioned recently by Hoelgaard from his inspectors. These allege that when the inspectors presented evidence in June 1990 of shortcomings in Britain's enforcement of BSE control measures such as failure to remove nerve tissues adequately - Keith Meldrum, the United Kingdom's chief veterinary officer, "exploded", according to Hoelgaard. Meldrum told the inspectors that they "had no mandate to investigate BSE controls", he says. Meldrum is said to have claimed that "BSE is a political not a technical matter" and that "UK certificates are the best in the world".

Collins says: "You need commissioners that can stand up to pressure from the member states", and ensure that regulations on health are enforced. BSE has shown that the principle of subsidiarity is flawed when it comes to health issues, says one official from the parliament. Collins argues that, while subsidiarity allows for the devolution of responsibilities to member states, the commission has a duty to ensure that regulations are respected. This means having "a strong inspection system that can override states, and that means a strong agriculture commissioner - which we now have".

A wider question is the extent to which the commission and member states have allowed economics to take priority over public health. The commission's line is that it has followed science all the way, and that it has sometimes gone beyond the science. But this interpretation is questioned by some observers, who protest at what they 
claim is excessive secrecy surrounding the commission's scientific committees, and question their legitimacy.

EU measures on BSE must be approved by either the standing veterinary committee - made up of the chief veterinary officers of member states - or the agriculture council. The commission submits proposals to them after taking advice from its scientific veterinary committee (SVC), made up scientists selected by the commission from nominations by the member states. The SVC itself has a working party on BSE, made up of outside experts.

The fact that members of the SVC are appointed by member states undermines its independence, argue critics. "While the commission says it relies on science, one wonders how objective this science is within these committees," says Collins. "People on these are almost all appointees of national governments and in some sense represent their government's points of view."

Such concerns are heightened by the secrecy in which the committees operate. "The problem is to know what the hell is going on in these committees," says one official at the parliament. Allegations of excessive secrecy are confirmed by Hoelgaard, who himself says: "Speaking as Dane, I have been quite shocked and amazed by procedures in the commission."

The competence of some members of the SVC is also questioned by some scientists. One recalls a meeting of the SVC in July on the risk of BSE in sheep. The SVC's working party on BSE had prepared "an interesting and rich working document", according to the observer, but it passed over the heads of most of those present.

The document was made available to the SVC only at the meeting, and committee members lacked time to consider it. The discussion, claims the observer, was "psychedelic" with "almost

half" the members

failing to grasp that

it concerned the risk of BSE in sheep, and not scrapie.

The creation last summer of a multidisciplinary committee on BSE to advise the commission is an admission of the flaws in the scientific veterinary

committee, according to observers. "The commission realized that it had to diminish the excessive power of DG6 [the agriculture directorate]," says one scientist involved.

Evidence of interference by DG6 comes from a stormy meeting of the industry directorate's scientific food committee on 8 March, almost two weeks before the UK government announced a possible link between BSE and CJD. One member of the committee says that Brian Marchant, a civil servant in DG6, disputed the meeting's decision not to take a position on the unilateral exclusion by France and Germany of certain bovine materials from baby food, because it considered that the risk of BSE could not be excluded. Marchant "treated us as if we were incompetent and thought we were wrong to take a position that was different from the scientific veterinary committee", he says.

One outcome of the BSE crisis, admits one commission official, is that it has vindicated the Parliament's long-standing criticism of the system of committees. The BSE crisis has exposed that this system means that it "is hard to see who is responsible" for decisions.

A wide-ranging reorganization of the commission services is likely to result from a confidential audit of DG6's veterinary services commissioned by Legras from the commission's general inspectorate, which reports direct to Jacques Santer, the commission president.

One official from the parliament's environment committee says it is keen to have animal health and its consequences for public health moved out of DG6. It wants this activity to be combined with health currently part of the directorate for employment and social affairs (DG5) - and shifted to the directorate for consumer protection (DG24). Only in this way can "the inherent conflict of interest" of handling health matters within the powerful agriculture directorate be avoided, he says. Declan Butler

\section{Australian reef fisheries project swims for survival}

Sydney. A decision by the Australian government to approve a project designed to evaluate the effects of line fishing and the rates of recovery of commercial and recreational species on the Great Barrier Reef (GBR) is being challenged in the federal parliament.

If the project proceeds, it will be the first controlled test of 'adaptive management' of coral reefs and the first in a marine World Heritage Area. Opposition to it focuses on the procedures for assessing the environmental impact of the survey, and on an alternative proposal for closing reefs as a precautionary measure.

Led by Bruce Mapstone, a biologist at the Cooperative Research Centre for Reef Research (CRC) in Townsville, Queensland, the programme is planned to last between five and ten years, and will be run in collaboration with the commercial and recreational fishing industries on 24 reefs selected from 3,000 within the $2,000-\mathrm{km}$ long GBR Marine Park.

In each of four clusters of six reefs, fishing will be allowed in two 'green reefs', currently closed to fishing. Two 'blue reefs' now open to fishing will be subjected to greater pressure for 12 months before being closed, and two reefs will be controls. After a year of measured harvesting, coral trout (the basis of the industry) are expected to decline by 50 to 60 per cent, and the fished reefs will be closed for five years to measure their rates of recovery.

Fisheries around the world experiencing sudden collapses have done so without warning. The GBR experiment follows studies by Campbell Davies of the CRC, showing that coral trout do not migrate between different reefs. It is designed to measure how vulnerable or robust a fishery is under the pressure of fishing, and the effectiveness of reef closures as a means of replenishing stocks.

The experiment is supported by the Australian Marine Sciences Association, and has been approved by Robert Hill, the Minister for the Environment. But there has been vehement opposition from local conservation groups, as well as the Australian Democrats Party in the Senate. They claim that Hill by-passed a legal requirement to take note of advice from statutory authorities - which he denies.

Meg Lees, the Democrats' environment spokeswoman, is seeking to reverse Hill's change of zoning regulations for the GBR, attacking him for bowing to pressure from the commercial industry and asserting that his policies "would rip the heart out of some of the few protected regions of the GBR".

\section{IMAGE UNAVAILABLE FOR COPYRIGHT REASONS}

All at sea? Critics point to conservation risks.

There have been only three other experiments in adaptive management, two in Canada and one in the Philippines. Carl Walters of the University of British Columbia, Canada, says that there is no direct experimental evidence to support adaptive management of reef fisheries. Most of the reefs in the GBR are now at risk of impacts from recreational and commercial fishing, he says. "We do not understand those impacts, and cannot model them correctly with available information." Peter Pockley 